https://unars.ac.id/ojs/index.php/pgsdunars/index

\title{
PERBANDINGAN PRESTASI BELAJAR MATEMATIKA SISWA BERDASARKAN DAYA NALAR MATEMATIS DAN BERFIKIR KRITIS DI KELAS VIII MTS SARJI AR-RASYID
}

\author{
Yesi Puspitasari ${ }^{1}$, Darsih Idayani ${ }^{2}$, dan Nuril Firdausia ${ }^{3}$ \\ 1,2,3 STKIP PGRI Situbondo \\ Corresponce Email: yesipuspita31@gmail.com
}

Received: May 10, 2020 Revised: May 16, $2020 \quad$ Accepted: May 19, 2020

\begin{abstract}
ABSTRAK
Untuk mengetahui kemampuan pembelajaran matematik tingkat tinggi baik perilaku berfikir secara logis pada siswa maka dibutuhkan daya nalar yang baik, kesanggupan, kecakapan, dan kekuatan dalam pembelajaran. Prestasi belajar juga dipengaruhi oleh daya nalar dan berfikir kritis siswa. Penelitian ini merupakan penelitian kualitatif. Terdapat tiga variabel dalam penelitian ini. Daya Nalar Matematis, Berfikir Kritis dan Prestasi Belajar. Data yang terkumpul akan dianalisis dengan statistik. Selanjutnya akan dilakukan uji validitas, kemudian di uji Reliabilitas untuk mengetahui instrumen yang reliabel, kemudian dilakukan uji Normalitas dan Uji One Way Anova.Lokasi penelitian di MTs Sarji Ar-Rasyid. Hasil Uji validitas responden sebanyak 34 siswa, maka $\mathrm{N}=34$ dan taraf signifikansi 5\% atau 0,05 sehingga $r_{\text {tabel }}=0,339$. Jika $r_{\text {hitung }}>r_{\text {tabel }}$ maka item dinyatakan valid dan jika $r_{\text {hitung }}<r_{\text {tabel}}$, maka item dinyatakan tidak valid tetapi dari 16 butir pernyataan, sebanyak 14 butir dinyatakan valid karena $r_{\text {hitung }}>r_{\text {tabel }}$ dan sebanyak 2 butir pernyataan dinyatakan tidak valid karena $\mathrm{r}_{\text {hitung }}<\mathrm{r}_{\text {tabel }}$. Hasil Uji Reliabilitas dari penghitungan SPSS Statistics 24 tersebut diperoleh Cronbach Alpha sebesar 0,823 yang berarti bahwa $\alpha>r_{\text {tabel }}$ atau 0,823>0,339 sehingga item angket daya nalar matematis dinyatakan reliabel. Data angket kemampuan berpikir kritis, diperoleh Cronbach Alpha sebesar 0,840 yang berarti bahwa $\alpha>r_{\text {tabel }}$ atau $0,840>0,339$ sehingga item angket kemampuan berpikir kritis juga dinyatakan reliabel. Uji normalitas Kolmogorov-Smirnov koefisien Sig. $>\alpha$ yaitu $0,200>0,05$ sehingga data prestasi belajar matematika siswa berdistribusi normal. Hasil anova dua arah (Nalar) diperoleh nilai probabilitas $\mathrm{F}_{\text {hitung }}$ atau Sig. $=0,048<0,05$. Maka $\mathrm{H}_{0}$ ditolak dan $\mathrm{H}_{\mathrm{a}}$ diterima. Nilai probabilitas $\mathrm{F}_{\text {hitung }}$ atau Sig. $=0.822>0,05$. Maka $\mathrm{H}_{0}$ diterima dan $\mathrm{H}_{\mathrm{a}}$ ditolak. Hasil anova dua arah (Nalar*Kritis) diperoleh nilai probabilitas $\mathrm{F}_{\text {hitung }}$ atau Sig. $=0,754>0,05$. Maka $\mathrm{H}_{0}$ diterima dan $\mathrm{H}_{\mathrm{a}}$ ditolak yang menghasilkan kesimpulan tidak ada interaksi daya nalar matematis dan kemampuan berpikir kritis dalam menentukan prestasi belajar matematika siswa diperoleh $\mathrm{R}$ Squared = 0,130 variabel daya nalar matematis dan kemampuan berpikir kritis secara bersama-sama mempengaruhi prestasi belajar matematika siswa sebesar $13 \%$
\end{abstract}

Kata kunci: Daya Nalar Matematis, Berfikir Kritis, Prestasi Belajar 


\begin{abstract}
To know the ability of high-level mathematical learning both logical thinking behavior in students, it take good reasoning ability, anility, skill, and strenghth in learning. Learning achievement is also. Influenced by student's reasoning and critical thiking skills. The research is a aquantitave reasearch. There are two variables in this study Mathematical Reasoning Power, Critical Thinking, and Learning achivement. Data collected will be analyzed statistically. Then the validity test will be conducted, then the Reliability test will be performed to find out the reliable instruments, then the Normality Tess and One Way Anova Test will be conduted

Research location at MTs Sarji Ar-Rasyid. The results of the validity test of the respondents were 34 students, then $\mathrm{N}=34$ and the significance level was $5 \%$ or 0.05 , so that $\mathrm{r}$ table $=$ 0.339. If rcount $>$ rtabel then the item is declared valid and if rcount <rtabel, then the item is declared invalid but from 16 statement items, 14 items are declared valid because rcount $>$ rtabel and 2 statements are declared invalid because rcount <rtabel. The results of the reliability test from the calculation of SPSS Statistics 24 obtained Cronbach Alpha of 0.823, which means that $\alpha>$ rtabel or $0.823>0.339$ so that the questionnaire item of mathematical reasoning was declared reliable. Questionnaire data for critical thinking skills, obtained by Cronbach Alpha of 0.840 , which means that $\alpha>r$ table or $0.840>0.339$ so that the critical thinking ability questionnaire item is also declared reliable. Kolmogorov-Smirnov normality test for the coefficient of Sig. $>\alpha$, namely $0.200>0.05$ so that he data on students' mathematics learning achievement is normally distributed. the results of the two-way ANOVA (Reason) obtained the probability value Fcount or Sig. $=0.048<0.05$. Then H0 is rejected and $\mathrm{Ha}$ is accepted. the probability value Fcount or Sig. $=0.822>0.05$. Then H0 is accepted and $\mathrm{Ha}$ is rejected. the results of the two-way ANOVA (Reasoning * Critical) obtained the probability value Fcount or Sig. $=0.754>0.05$. Then H0 is accepted and Ha is rejected which results in the conclusion that there is no interaction between mathematical reasoning and critical thinking skills in determining student mathematics learning achievement. obtained $\mathrm{R}$ Squared $=0.130$, the variable mathematical reasoning power and the ability to think critically affect students' mathematics learning achievement by $13 \%$
\end{abstract}

\title{
Keywords: Mathematical Reasoning Power, Critical Thinking, and Learning Achivement
}

\section{PENDAHULUAN}

Prestasi belajar sebagai produk akhir kegiatan belajar tidaklah diperoleh dengan cara dan prosedur sederhana. Namun, prestasi belajar menjadi gambaran menyeluruh dari kegiatan yang dilakukan siswa baik aktifitas mental dan spiritual (Wijayanti dan Harini, 2014).

Nafiah dan Rahmaningtyas (2009) menyatakan bahwa daya nalar adalah kesanggupan, kecakapan, dan kekuatan yang lebih ditekankan pada aspek berpikir yang dimiliki seseorang dalam merespons simbol, premis untuk membuat kesimpulan secara logis, meliputi beberapa aspek kemampuan: melakukan perhitungan matematis, berpikir logis, memecahkan masalah, pola pikir deduksi dan induksi, dan mengenali pola dan hubungan. Matematika melatih cara berpikir dan bernalar dalam menarik kesimpulan,misalnya melalui kegiatan penyelidikan,eksplorasi, eksperimen, menunjukankesamaan, perbedaan, konsisten, daninkonsistensi (Somatanaya, 2017). Oleh karena itu, kemampuan dalam menalar menjadi salah satu faktor yang paling utama dalam kegiatan pembelajaran. 
MTs Sarji Ar-Rasyid merupakan salah satu sekolah jenjang menengah pertama di Situbondo yang juga telah menerapkan kurikulum K13. Pada pembelajaran matematika kurikulum K13, siswa seharusnya terlibat secara aktif dalam proses pencarian dan penerimaan informasi. Pembelajaran berbasis masalah di mana soal-soal yang ditampilkan mencakup banyak perbedaan dalam penyelesaiannya.Banyaknya penyelesaian bergantung pada kemampuan siswa dalam mengolah nalar mereka.

\section{BAHASAN UTAMA}

Prestasi belajar adalah hasil evaluasi peserta didik dengan menggunakan alat penilaian setelah dilakukan proses pembelajaran secara terencana baik materi maupun waktunya serta prestasi belajar yang diinginkan disesuaikan dengan jenis dan fungsinya dalam penilaian atau pengukuran (Cleopatra, 2015).

Menurut Vandini (2015), prestasi belajar matematika dipengaruhi oleh faktor internal dan eksternal. Faktor internal merupakan faktor yang berasal dari dalam diri sendiri, seperti motivasi, kecerdasan emosional, kepercayaan diri, kemandirian, dan lain-lain. Sedangkan faktor eksternal merupakan faktor yang berasal dari luar diri sendiri, seperti sarana dan prasarana, lingkungan, guru, dan metode dalam mengajar.

Prestasi belajar yang hendak dicapai oleh siswa dikelompokkkan menjadi 3 (tiga) ranah, yaitu kognitif, afektif, dan psikomotorik. Prestasi atau keberhasilan belajar dapat dioperasionalkan dalam bentuk indikator-indikator berupa nilai rapor, indeks prestasi studi, angkakelulusan, predikat keberhasilan, dan lainsebagainya. Dengan demikian, prestasi belajartidak hanya aspek pengetahuan saja, namun jugameliputi keseluruhan aspek yaitu kognitif, afektif,dan psikomotor yang diwujudkan dalam bentuknilai atau angka yang menunjukkan suatu prestasi Azwar (dalam Mulyaningsih, 2014).

Penalaran (reasoning) adalah suatu proses yang dilakukan untuk mencapai kesimpulan yang logis berdasarkan ilmu pengetahuan yang berkaitan dengan faktaserta berbagai sumber yang relevan. Aktivitas bernalar harus dilakukan oleh para siswa, jika mereka tidak melakukan aktivitas bernalar ketika belajar maka apa yang mereka peroleh hanya sekedar hafalan dan tidak memahami inti ataupun konsep dari materi yang telah dipelajari.

Dengan adanya aktivitas penalaran ketika belajar, maka siswa akan mendapatkan suatu kesimpulan yang benar mengenai materi yang dipelajari karena sudah melalui proses berpikir yang logis ketika belajar (Amir, 2014). Kemampuan penalaran matematis membantu siswa dalam menyimpulkan dan membuktikan suatu pernyataan, membangun gagasan baru, sampai pada menyelesaikan masalah-masalah dalam matematika. Oleh karena itu, kemampuan penalaran matematis harus selalu dibiasakan dan dikembangkan dalam setiap pembelajaran matematika (Sumartini, 2015).

Kemampuan individu untuk menggunakan nalar mereka terbagi menjadi 3 (tiga) instrumen. Pertama adalah nalar secara predikabel, yaitu kemampuan individu untuk mengenal atau mengidentifikasi pengertian yang dinyatakan oleh predikat subyeknya. Kedua nalar secara klasifikasi, 
yaitu kemampuan individu untuk menggolongkan pernyataan-pernyataan tertentu berdasarakan kesamaan atau perbedaannya. Yang ketiga adalah nalar secara inferensi adalah proses individu melakukan penarikan kesimpulan dalam artian individu mampu merangkum atau menyimpulkan informasi yang sebelumnya telah diolah nalarnya. Menurut Ario (2016) indikator penalaran matematis ada 4 (empat), yaitu: 1) memeriksa validitas argumen; 2) membuat analogi dan generalisasi; 3) menarik kesimpulan logis; 4) mengikuti aturan inferensi.

Tabel 2.1 Indikator dan Uraian dalam Penalaran Matemati

\begin{tabular}{lll}
\hline No & Indikator Penalaran Matematis & Uraian \\
\hline 1. & Memeriksa validitas argumen & 1. Menjelaskan permasalahan di dalam soal \\
& & 2. Menyebutkan apa yang diketahui dan ditanyakan pada soal \\
& & 3. Menjabarkan pernyataan dan memberi penjelasan yang \\
& & dapat mendukung pernyataan yang dijabarkan
\end{tabular}

Sumber; Ario (2016)

Berpikir kritis menurut Rahmawati(2014) dianggap sebagai proses utama dan tujuan pendidikan berisi tentang: pengakuan akan persoalan penting yang selayaknya berdasarkan pertimbangan, berpikir bijak tentang perumusan pertanyaan yang bagus, sebuah pencarian untuk jawaban yang mungkin dan bukti yang saling berhubungan, pertimbangan pendapat cadangan, dan menarik kesimpulan sementara sampai jawaban yang terbaik didapatkan.

Berpikir kritis (critical thinking) adalah kemampuan dalam menganalisis dan mengevaluasi informasi yang didapat dari hasil pengamatan, pengalaman, penalaran maupun komunikasi untuk memutuskan apakah informasi tersebut dapat dipercaya sehingga dapat memberikan kesimpulan yang rasional dan benar. Indikator berpikir kritis yang digunakan dalam penelitian ini dapat dilihat pada Tabel 2.1.Sebagai berikut;

Tabel 2.2 Indikator Kemampuan berfikir Kritis.

\begin{tabular}{lll}
\hline No & Indikator & Keterangan Indikator \\
\hline 1. & Interpretasi & $\begin{array}{l}\text { Memahami masalah yang ditunjukkan dengan menulis yang diketahui maupun } \\
\text { yang ditanyakan soal dengan tepat }\end{array}$ \\
\hline 2. & Analisis & $\begin{array}{l}\text { Mengidentifikasi hubungan-hubungan antara pernyataan-pernyataan, } \\
\text { pertanyaan-pertanyaan, konsep-konsep yang diberikan dalam soal yang } \\
\text { ditunjukkan dengan membuat model matematika dengan tepat dan memberi } \\
\text { penjelasan yang tepat }\end{array}$ \\
\hline
\end{tabular}



\begin{tabular}{ll}
\hline 3. Evaluasi & $\begin{array}{l}\text { Menggunakan strategi yang tepat dalam menyelesaikan soal, lengkap, dan } \\
\text { benar dalam melakukan perhitungan. }\end{array}$
\end{tabular}

4. Inferensi Dapat menarik kesimpulan dari apa yang ditanyakan dengan tepat

Sumber; (Ratna Purwati, Hobri, dan Arif Fatahillah, 2017).

\section{METODE PENELITIAN}

Metode yang digunakan dalam penelitian adalah penelitian kuantitatif. Dalam penelitian kuantitatif, masalah yang dibawa oleh peneliti sudah jelas (Sugiyono, 2016:30). Metode penelitian kuantitatif dipilih karena peneliti hendak menguji teori secara langsung di lapangan bersandarkan pada teori yang sebelumnya telah ada. Sementara itu, desain yang digunakan dalam penelitian adalah deskriptif kuantitatif.

Penelitian dilaksanakan dengan menyebarkan angket daya nalar terhadap siswa, kemudian mendokumentasi data prestasi belajar dari hasil nilai belajar matematika pada rapor siswa. Selanjutnya, data diolah dan dilakukan uji beda sebagai uji hipotesis. Teknik penentuan lokasi penelitian dilakukan MTs Sarji Ar-Rasyid. Teknik penentuan responden penelitian dengan sebagai beriku;

1) Populasi

Populasi dalam penelitian ini adalah seluruh siswa kelas VIII di MTs Sarji Ar-Rasyid

2) Sampel

Teknik pengambilan sampel penelitian inadalah nonprobability sampling, yaitu pengambilan sampel dengan pusposive dan bersifat objektif dengan teknik purposive sampling, sampel dalam penelitian ini kelas VIII di MTs Sarji Ar-Rasyid.

Teknik pengumpulan data meliputi; 1) observasi, 2) Angket (Kuesioner), 3) Dokumentasi.

Teknik analisis data pada penelitian sebagai berikut;

\section{Uji validitas :}

$$
r_{x y}=\frac{N\left(\sum X Y\right)-\left(\sum Y\right)\left(\sum Y\right)}{\sqrt{\left\{N\left(\sum X^{2}\right)-\left(\sum X\right)^{2}\right\}\left\{N\left(\sum Y^{2}\right)-\left(\sum Y\right)^{2}\right\}}}
$$

Keterangan: (Supandi dan Farikhah, 2016)

$r_{x y}=$ Koefisien korelasi product moment

$\mathrm{N} \quad=$ Jumlah objek

$\mathrm{X} \quad=$ Skor butir item

$\mathrm{Y} \quad=$ Skor total

$\mathrm{Uji} \mathrm{t}: t_{\text {hitung }}=\frac{r \sqrt{n-2}}{\sqrt{1-r^{2}}}$

Di mana;

$$
\begin{aligned}
& \mathrm{t}=\text { Nilai } \mathrm{t}_{\text {hitung }} \\
& \mathrm{r}=\text { Koefisien korelasi hasil } \mathrm{r}_{\text {hitung }} \\
& \mathrm{n}=\text { Jumlah responden }
\end{aligned}
$$

Distribusi (Tabel t) untuk $\alpha=0,005$ dan derajat kebebasan $\{\mathrm{dk}=\mathrm{n}-2\}$

Kaidah keputusan; 
jika $t_{\text {hitung }}>t_{\text {tabel }}$ berarti valid $t_{\text {hitung }}<t_{\text {tabel }}$ berarti tidak valid.

\section{Uji Realibilitas:}

Suatu variabel dikatakan reliabel jika memberikan nilai $\alpha$ lebih dari 0,60. Sedangkan jika nilai $\alpha$ kurang dari 0,60 maka variabel tersebut tidak reliable. reliabilitas item digunakan rumus CronbachAlpha, yaitu:

$r_{11}=\left[\frac{n}{(n-1)}\right]\left[1-\frac{\sum s_{i}^{2}}{s_{i}^{2}}\right]$

(Supandi dan Farikhah, 2016)

Keterangan:

$r_{11}=$ Reliabilitas instrumen

$n \quad=$ Banyaknya butir pertanyaan

$\sum s_{i}^{2} \quad=$ Jumlah varians skor tiap item

$s_{i}^{2} \quad=$ Varians total

Sedangkan varians butir item menggunakan formula;

$\sum s_{i}^{2}=\frac{\sum X^{2}-\frac{\left(\sum X\right)^{2}}{N}}{N}$

Keterangan:

$\sum s_{i}^{2} \quad=$ Jumlah varians skor tiap item

$\sum X^{2} \quad=$ Jumlah skor butir item

$N \quad=$ Jumlah objek

\section{Uji Normalitas:}

Uji normalitas menggunakan uji Kolmogorov-Smirnov setiap data variabel penelitian pada taraf signifikansi $\alpha$ yang dipilih biasanya

$\alpha=0,05$ (Indrawan dan Yaniawati, 2014:166).

Kriteria pengujian menggunakan SPSS dengan ketentuan:

Terima $\mathrm{H}_{0}$ : Data berdistribusi normal, jika

nilai sig $\geq \alpha$

Terima $\mathrm{H}_{\mathrm{a}}$ : Data tidak berdistribusi normal,

jika nilai sig $\leq \alpha$

\section{One Way Anova:}

Anova dikenal dengan uji $\mathrm{F}$ (Fisher test), sedangkan arti variansi atau varians berasal dari pengertian konsep "Mean square" atau Kuadrat Rerata (KR). Rumusnya adalah:

Keterangan:

$$
K R=\frac{J K}{d k}(\text { Riduwan \& Sunarto, 2017: 132) }
$$

$\mathrm{JK}=$ Jumlah kuadrat (some of square)

$\mathrm{Dk}=$ Derajat kebebasan (degree of freedom) Menghitung nilai anova atau $\mathrm{F}_{\text {hitung }}$ dengan rumus;

$$
F_{\text {hitung }}=\frac{V_{A}}{V_{D}}=\frac{K R_{A}}{K R_{D}}=\frac{J K_{A}: d k_{A}}{J K_{D}: d k_{D}}=\frac{\text { Varians antar group }}{\text { Varians dalam group }}
$$

Varians Dalam Group disebut Varians Kesalahan (Varians Galat). Lebih lanjut dapat dirumuskan; 
$J K_{A}=\sum \frac{\left(\Sigma X_{A i}\right)^{2}}{n_{A i}}-\frac{\left(\Sigma X_{r}\right)^{2}}{N}$ untuk $\mathrm{dk}_{\mathrm{A}}=\mathrm{A}-1$

$J K_{D}=\sum X_{r}^{2}-\sum \frac{\left(\sum X_{A i}\right)^{2}}{n_{A i}}$ untuk $\mathrm{dk}_{\mathrm{D}}=\mathrm{N}-\mathrm{A}$

$\frac{\left(\Sigma X_{r}\right)^{2}}{N} \quad=$ sebagai faktor koreksi

$N=$ Jumlah keseluruhan sampel (jumlah kasus dalam penelitian)

$A=$ Jumlah keseluruhan group sampel

Kaidah keputusan:

Jika $\mathrm{F}_{\text {hitung }}>\mathrm{F}_{\text {tabel, }}$, maka $\mathrm{H}_{0}$ diterima dan $\mathrm{H}_{\mathrm{a}}$ ditolak

Jika $\mathrm{F}_{\text {hitung }}<\mathrm{F}_{\text {tabel }}$, maka $\mathrm{H}_{0}$ ditolak dan $\mathrm{H}_{\mathrm{a}}$ diterima

\section{HASIL DAN PEMBAHASAN}

\section{Data Daya Nalar dan Kemampuan Berpikir Kritis} 1

Penghitungan interval digunakan untuk membagi daya nalar menjadi dua sapek adalah

$$
\begin{aligned}
\text { Interval }=\frac{\text { Poin maksimal }- \text { Poin minimal }}{\text { Jumlah aspek }} \\
=\frac{70-14}{2} \\
=\frac{56}{2} \\
=28
\end{aligned}
$$

Tabel 1 Klasifikasi Daya Nalar

\begin{tabular}{cc}
\hline \multicolumn{1}{l}{ nterval Poin } & Kategori \\
\hline $14-42$ & Rendah \\
\hline $43-70$ & Tinggi \\
\hline
\end{tabular}

Berdasarkan Klasifikasi daya nalar pada tabel 4.1 siswa dengan kategori daya nalar matematis rendah sebanyak 10 orang. Dikarenakan kesepuluh orang siswa mendapatkan jumlah poin angket dari rentang 14 - 42. Siswa dengan kategori daya nalar natematis tinggi sebanyak 24 orang. Hal ini dikarenakan kedua puluh empat orang siswa tersebut mendapatkan jumlah poin angket dari rentang 43 -70 .

\section{Data Prestasi Belajar Matematika}

Tabel 2 Distribusi Frekuensi Nilai Matematika Siswa

\begin{tabular}{ccc}
\hline Kelas ke- & Nilai & Frekuensi (Fi) \\
\hline 1 & $75-76$ & 1 \\
\hline 2 & $77-78$ & 7 \\
\hline 3 & $79-80$ & 15 \\
\hline 4 & $81-82$ & 10 \\
\hline 5 & $83-84$ & 1 \\
\hline Jumlah & & $\mathbf{3 4}$ \\
\hline
\end{tabular}




\begin{tabular}{ll}
\hline Median & $\mathbf{8 0}$ \\
\hline Modus & $\mathbf{7 9}$ \\
\hline
\end{tabular}

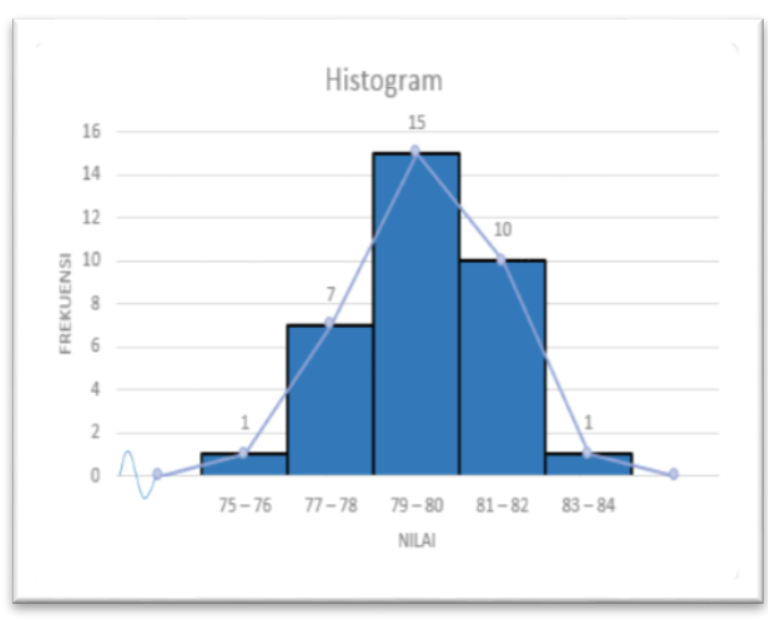

1. Histogram Nilai Rapor Matematika

Terdapat dua interval yang memperoleh frekuensi sama dengan nilai yang paling sedikit muncul yaitu interval $75-76$ dan $83-84$ dengan frekuensi masing-masing adalah 1. Nilai yang diperoleh kebanyakan siswa adalah pada interval 79 - 80 dengan frekuensi sebanyak 15.

\section{Data Prestasi Belajar Matematika Berdasarkan Daya Nalar}

Siswa yang memiliki prestasi belajar dengan daya nalar matematis tinggi sebanyak 24 orang dan siswa yang memiliki prestasi belajar dengan daya nalar rendah sebanyak 10 orang.

Tabel 3. Distribusi Frekuensi Prestasi Belajar dengan Daya Nalar Rendah

\begin{tabular}{ccc}
\hline Kelas ke- & Nilai & $\begin{array}{c}\text { Freku } \\
\text { ensi }\end{array}$ \\
\hline 1 & $76-77$ & 3 \\
\hline 2 & $78-79$ & 4 \\
\hline 3 & $80-81$ & 3 \\
\hline Jumlah & & $\mathbf{1 0}$ \\
\hline Mean & & $\mathbf{7 8 , 6}$ \\
\hline Median & & $\mathbf{7 8 , 4}$ \\
\hline Modus & & $\mathbf{7 7}$ \\
\hline
\end{tabular}

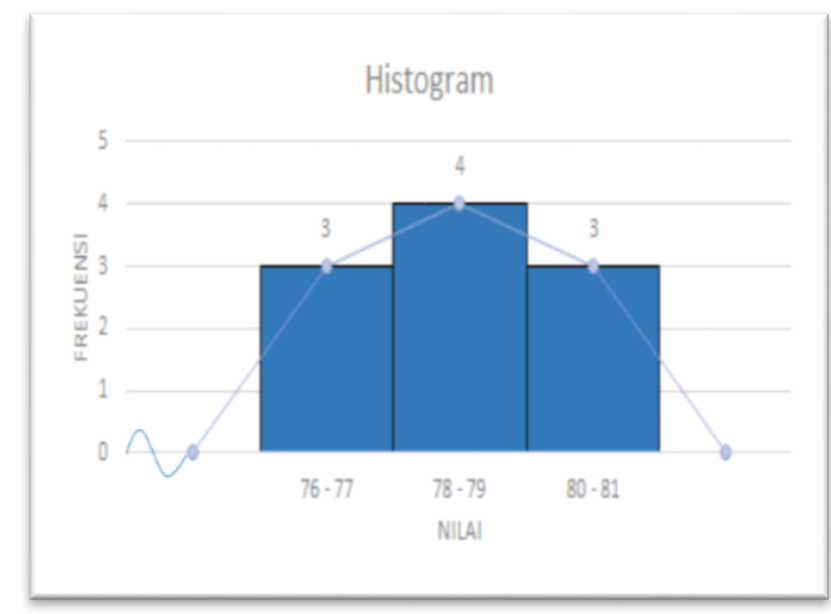

2. Histogram Prestasi Belajar Siswa dengan Daya Nalar Rendah

Siswa yang memiliki prestasi belajar dengan daya nalar tinggi sebanyak 10 orang. Frekuensi nilai yang banyak muncul pada kelas ke-1 dengan jumlah frekuensi 3 dan yang paling sedikit muncul pada kelas ke-5 dengan frekuensi 1.

Tabel 4. Distribusi Frekuensi Prestasi Belajar dengan Daya Nalar Tinggi 


\begin{tabular}{ccc}
\hline Kelas ke- & Nilai & Frekuensi \\
\hline 1 & $75-76$ & 1 \\
\hline 2 & $77-78$ & 2 \\
\hline 3 & $79-80$ & 11 \\
\hline 4 & $81-82$ & 9 \\
\hline 5 & $83-84$ & 1 \\
\hline Jumlah & & $\mathbf{2 4}$ \\
\hline Mean & & $\mathbf{7 9 , 9 6}$ \\
\hline Modian & & $\mathbf{8 0}$ \\
\hline
\end{tabular}

\section{Histogram Prestasi belajar dengan Daya Nalar Tinggi}

Siswa yang memiliki prestasi belajar dengan daya nalar tinggi sebanyak 24 orang. Frekuensi nilai yang banyak muncul adalah pada interval ke-3 yaitu 79 - 80 dengan jumlah frekuensi 11. Nilai siswa pada data prestasi belajar dengan daya nalar tinggi yang paling banyak muncul adalah 79, hal ini bisa dilihat dari jumlah modus. Nilai ini muncul pada kelas ke-3 pada interval nilai $79-80$.

\section{Prestasi Belajar Berdasarkan Kemampuan Berpikir Kritis}

Siswa dengan prestasi belajar matematika yang memiliki kemampuan berpikir kritis rendah sebanyak 11 orang sedangkan siswa dengan prestasi belajar matematika yang memiliki kemampuan berpikir kritis tinggi sebanyak 23 orang.

Tabel 5. Prestasi Belajar dengan Kemampuan Berpikir Kritis Rendah

\begin{tabular}{lcc}
\hline Kelas ke- & Interval Nilai & Frekuensi \\
\hline 1 & $77-78$ & 2 \\
\hline 2 & $79-80$ & 5 \\
\hline 3 & $81-82$ & 4 \\
\hline Jumlah & & $\mathbf{1 1}$ \\
\hline Rata-rata & $\mathbf{7 9 , 5 4}$ \\
\hline Median & $\mathbf{7 9}$ \\
\hline Modus & $\mathbf{7 9}$ \\
\hline
\end{tabular}

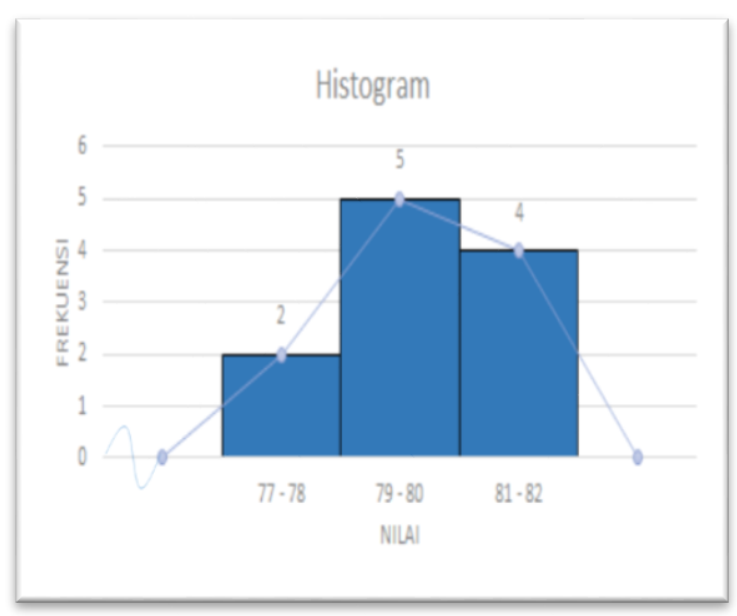

4. Histogram Prestasi Belajar dengan Kemampuan Berpikir Kritis Rendah

Siswa yang memiliki prestasi belajar dengan kemampuan berpikir kritis rendah paling banyak memperoleh nilai matematika pada rentang ke $79-80$. Hal ini dapat dilihat dari banyaknya 
frekuensi, yaitu 5 orang. Rata-rata prestasi belajar dalam kategori ini sebesar 79,54 dengan nilai yang paling banyak muncul (modus) adalah 79 .

Tabel 6. Prestasi Belajar dengan Kemampuan Berpikir Kritis Tinggi

\begin{tabular}{ccc}
\hline Kelas ke- & Interval Nilai & Frekuensi \\
\hline 1 & $75-76$ & 1 \\
\hline 2 & $77-78$ & 5 \\
\hline 3 & $79-80$ & 10 \\
\hline 4 & $81-82$ & 6 \\
\hline 5 & $83-84$ & 1 \\
\hline Rumlah & & $\mathbf{2 3}$ \\
\hline Median & & $\mathbf{7 9 , 5 6}$ \\
\hline Modus & & $\mathbf{8 0}$ \\
\hline
\end{tabular}

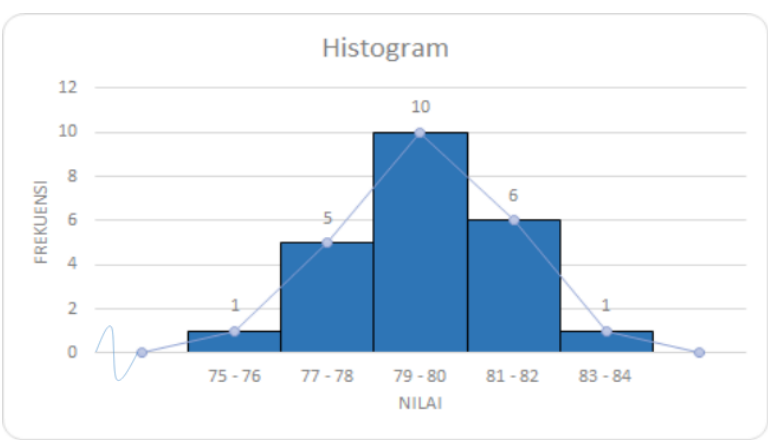

5. Histogram Prestasi Belajar dengan Kemampuan Berpikir Kritis Tinggi

Siswa yang memiliki prestasi belajar dengan kemampuan berpikir kritis tinggi paling banyak memperoleh nilai matematika pada rentang ke 79 - 80. Hal ini dapat dilihat dari banyaknya frekuensi, yaitu 10 orang. Rata-rata prestasi belajar dalam kategori ini sebesar 79,56 dengan nilai yang paling banyak muncul (modus) adalah 80 .

\section{Uji Validitas}

Hasil tabel Validitas Angket Daya Nalar dengan responden sebanyak 34 siswa, maka $\mathrm{N}=34$ dan taraf signifikansi 5\% atau 0,05 sehingga $\mathrm{r}_{\text {tabel }}$ $=0,339$. Jika $r_{\text {hitung }}>r_{\text {tabel }}$ maka item dinyatakan valid dan jika $r_{\text {hitung }}<r_{\text {tabel }}$, maka item dinyatakan tidak valid. Dari 16 butir pernyataan, sebanyak 14 butir dinyatakan valid karena $r_{\text {hitung }}>r_{\text {tabel }}$ dan sebanyak 2 butir pernyataan dinyatakan tidak valid karena $r_{\text {hitung }}<r_{\text {tabel. }}$. Hasil Validitas Angket Kemampuan Berpikir Kritis dari 20 butir pernyataan, sebanyak 19 butir dinyatakan valid karena $r_{\text {hitung }}$ $>\mathrm{r}_{\text {tabel }}$ dan sebanyak 1 butir pernyataan dinyatakan tidak valid karena $\mathrm{r}_{\text {hitung }}<\mathrm{r}_{\text {tabel }}$.

\section{Uji Reliabilitas}

Banyaknya butir angket yang diuji reliabilitasnya adalah 14 butir pernyataan untuk data angket daya nalar matematis dan sebanyak 19 butir pernyataan untuk data angket kemampuan berpikir kritis. Hasil penghitungan SPSS Statistics 24 tersebut diperoleh Cronbach Alpha sebesar 0,823 yang berarti bahwa $\alpha>r_{\text {tabel }}$ atau 0,823 $>0,339$ sehingga item angket daya nalar matematis dinyatakan reliabel.

Untuk data angket kemampuan berpikir kritis, diperoleh Cronbach Alpha sebesar 0,840 yang berarti bahwa $\alpha>r_{\text {tabel }}$ atau $0,840>0,339$ sehingga item angket kemampuan berpikir kritis juga dinyatakan reliabel. 


\section{Uji Normalitas}

Variabel prestasi belajar matematika yang diambil dari data nilai rapor matematika semester ganjil pada bagian uji normalitas Kolmogorov-Smirnov menunjukkan koefisien Sig. $>\alpha$ yaitu 0,200 >0,05 sehingga data prestasi belajar matematika siswa dinyatakan berdistribusi normal.

\section{PENGUJIAN HIPOTESIS}

1) Pengujian hipotesis 1

Berdasarkan hasil anova dua arah pada Tabel 4.16 yaitu baris ke-3 (Nalar) diperoleh nilai probabilitas $F_{\text {hitung }}$ atau Sig. $=0,048<0,05$. Maka $\mathrm{H}_{0}$ ditolak dan $\mathrm{H}_{\mathrm{a}}$ diterima. Sehingga dapat disimpulkan bahwa ada perbedaan prestasi belajar matematika siswa berdasarkan daya nalar matematis

2) Pengujian hipotesis 2

Berdasarkan hasil anova dua arah pada Tabel 4.16 yaitu baris ke-4 (Kritis) diperoleh nilai probabilitas $\mathrm{F}_{\text {hitung }}$ atau Sig. $=0.822>0,05$. Maka $\mathrm{H}_{0}$ diterima dan $\mathrm{H}_{\mathrm{a}}$ ditolak. Sehingga dapat disimpulkan bahwa tidak ada perbedaan prestasi belajar matematika siswa berdasarkan kemampuan berpikir kritis

3) Pengujian hipotesis 3

Berdasarkan hasil anova dua arah pada Tabel 4.16 yaitu baris ke-5 (Nalar*Kritis) diperoleh nilai probabilitas $F_{\text {hitung }}$ atau Sig. $=0,754>0,05$. Maka $\mathrm{H}_{0}$ diterima dan $\mathrm{H}_{\mathrm{a}}$ ditolak yang menghasilkan kesimpulan tidak ada interaksi daya nalar matematis dan kemampuan berpikir kritis dalam menentukan prestasi belajar matematika siswa

Besarnya kombinasi nilai variabel independen secara simultan atau bersama-sama mempengaruhi nilai variabel dependen, atau disebut juga nilai determinasi berganda semua variabel independen dengan dependen dapat dilihat dari besarnya R Squared. Dari tabel di atas, diperoleh $\mathrm{R}$ Squared $=0,130$ berarti bahwa variabel daya nalar matematis dan kemampuan berpikir kritis secara bersama-sama mempengaruhi prestasi belajar matematika siswa sebesar $13 \%$. 


\section{DAFTAR PUSTAKA}

Annisah, S. 2014. "Alat Peraga Pembelajaran Matematika”. Jurnal Tarbawiyah. Volume 10 Nomor 1 Edisi Januari- Juni 2014.

Binangun, H.H..and Hakim, R.A. 2016. "Pengaruh Penggunaan Alat Peraga Jam Sudut Terhadap Hasil Belajar Matematika".Jurnal JKPM. Volume 1 No. 2 Juni 2016.

Diah, N.S.B. 2014.Strategi Kebut Semalam Matematika SMP. Yogyakarta : Penerbit Cakrawala.

Dian, M. 2014. "Perbandingan Metode Diskusi dan Demosntrasi Terhadap Hasil Belajar Matematika Pokok Bahasan Bangun Ruang".Jurnal PHYTAGORAS. Volume.03 No. 2 Bulan tidak diterbitkan 2014.

Habibah, M 2013.“Pengaruh Penggunaaan Alat Peraga Model Segitiga Pada Pembelajaran Bidang Datar Terhadap Hasil Belajar Siswa".Jurnal Mathematics Education Learning And Teaching. Volume 2 No. 1 Bulan tidak diterbitkan 2013.

Husmul dkk, 2015."Pengaruh Penggunaan Media Alat Peraga Terhadap Hasil Belajar Siswa pada Materi Sistem Peredaran Darah Kelas VIII SMP Negeri 2 Bulukumba".Jurnal Sainsmat. Volume 04 No.1 Maret 2015.

Ibrahim, R. And Syaodih, N. 2010. Perencanaan Pengajaran. Jakarta : Penerbit Rineka Cipta. 
Ibrahim, 2017."Perpaduan Model Pembelajaran Aktif Konvensional (Ceramah) Dengan Cooperatif (Make- A Match) Untuk Meningkatkan Hasil Belajar Pendidikan Kewarganegaraan".Jurnal Pendidikan Sosial, Sains, dan Humaniora. Volume 03 No. 2 Juni 2017.

Jamilah, S. and Akbar, O.R. 2016."Pengaruh Penggunaan Alat Peraga AEM (Algebraic Experience Materials) Terhadap Keterampilan Berpikir Kreatif Siswa Pokok Bahasan Operasi Aljabar".Jurnal Eduma. Volume 5 No. 1 Juli 2016.

Jauhar, M. 2011. Implementasi PAIKEM dari Behavioristik Sampai Kontruktivistik.Jakarta : Penerbit Prestasi Pustaka.

Indrawan.R. dan Yaniawati.P.2014. Metodologi Penelitian Kuantitatif,Kualitatif, dan Campuran untuk Manjement,Pembangunan, dan Pendidikan. Bandung: Refika ADITAMA.

Lastrijanah. 2017. "Pengaruh Penggunaan Media Pembelajaran Geoboard Terhadap Hasil Belajar Siswa. Jurnal Didaktika Tauhidi. Volume 4 No. 2 Oktober 2017.

Masturoh, I. and Khaerani. 2017. "Pengaruh Penggunaan Alat Peraga Geoboard Terhadap Hasil Belajar Siswa Pada Pokok Bahasan Geometri”. Jurnal Primary. Volume 09 No. 02 (JuliDesember) 2017.

Mustadi dkk. 2017. "Perbandingan Hasil Belajar Matematika Dengan Menggunakan Metode Pembelajaran Make A Match Dan Scramble Pada Peserta Didik Kelas IV SD Inpres Tanah Kareng”. Jurnal Pendidikan Matematika dan Pembelajaran.Volume 5 No. 1 Juni 2017.

Nella, E. 2014." Perbandingan Pembelajaran Konvensional dan Pembelajaran Berbasis Masalah terhadap Titik Jenuh Siswa Maupun Hasil Belajar Siswa dalam Pembelajaran Matematika". Jurnal Educatio Vitae.Volume 01 No. 12014.

Nursuprianah, I. and Ani. 2010. "Pengaruh Penggunaan Alat Peraga Lingkaran Terhadap Hasil Belajar Siswa Kelas VIII Pada Pembelajaran Keliling Dan Luas Lingkaran”. Jurnal Eduma. Volume 02 No. 1 Juni 2010.

Setyowati, N. 2016."Penggunaan Alat Peraga untuk Meningkatkan Hasil Belajar dan Keaktifan Siswa pada Materi Peluang”.Jurnal Kreano. Volume 7 No. 1 Juni 2016

Simanulang, J. 2013. "Pengembangan Bahan Ajar Materi Himpunan Konteks Laskas Pelangi Dengan Pendekatan Pendidikan Matematika Realistik Indonesia (PMRI) Kelas VII Sekolah Menengah Pertama". Jurnal Pendidikan Matematika. Volume 2 No. 2 Juli 2013.

Sugiyono, 2014.Metode Penelitian Kuantitatif Kualitatif Dan $R \&$ \& . Bandung : Penerbit Alfabeta.

Susanto, A. 2013.Teori Belajar dan Pembelajaran Di Sekolah Dasar.Jakarta : Penerbit Kencana.

Suharmanto. 2014. "Pengembangan Media Pembelajaran Papan Hitung Pembagian Pada Mata Pelajaran Matematika Sekolah Dasar Kelas 2". Jurnal Tekhnologi Pendidikan. Desember2016

Suwardi. 2014. "Pengaruh Penggunaan Alat Peraga terhadap Hasil Pembelajaran Matematika pada Anak Usia Dini”. Jurnal AL-AZHAR INDONESIA SERI HUMANIORA. Volume 2 No.4 September 2014. 